\title{
Promoting the Entrepreneurial Success of Women Entrepreneurs Through Education and Training
}

\author{
Käthe Schneider \\ Faculty of Social and Behavioural Sciences, Friedrich-Schiller-University of Jena, Jena, Germany \\ Email address: \\ k.schneider@uni-jena.de

\section{To cite this article:} \\ Käthe Schneider. Promoting the Entrepreneurial Success of Women Entrepreneurs Through Education and Training. Science Journal of \\ Education. Vol. 5, No. 2, 2017, pp. 50-59. doi: 10.11648/j.sjedu.20170502.13
}

Received: February 23, 2017; Accepted: March 7, 2017; Published: March 21, 2017

\begin{abstract}
To support early stage women entrepreneurs there is a need to increase their performance and growth potential through entrepreneurial education and training. The objective of the study is to develop a theoretically and empirically based entrepreneurship education and training for early stage women entrepreneurs. The focus of this study is placed exemplarily on early stage women entrepreneurs in Germany and Ireland. The components, program goals, program elements, as well as the participants' characteristics, the program's contextual environment, and the availability of funding for operations provide a framework for designing a theoretically and empirically based program to help early stage women entrepreneurs increase their entrepreneurial success. This Entrepreneurship Education and Training is built on the core dimensions of entrepreneurship education action-orientation, autonomy and the interplay between risk and responsibility. Action-orientation is reflected in acting in learning to solve business problems in one's own company. Autonomy is manifested by selecting individual learning objectives. Interplay between risk and responsibility is shown through taking responsibility for individual and organizational development, which participants will learn is in part a risk-taking process. Because we expand on these core dimensions, entrepreneurial learning can be understood as learning through entrepreneurial action, reflection and narration. The design of the program targeted at early stage women entrepreneurs not only shows how the core components of an entrepreneurial education and training program can be designed for the specific target group of early stage women entrepreneurs in Germany and Ireland, but also how the Entrepreneurship Education and Training Effectiveness Framework can be enriched. We include the process of deriving program and learner goals as a critical starting point for designing programs affecting both learning performance and outcome.
\end{abstract}

Keywords: Entrepreneurship Education, Women Entrepreneurs, Education and Training

\section{Introduction}

Over the past twenty years there has been keen scientific interest in research on women's entrepreneurship [2, 6-8, 10, 29, 36-37]. Entrepreneurship is regarded as contributing to economic, cultural, social, and also ecological improvements, as postulated, for example, in the frame of the Europe 2020 Strategy [11], and also to personal joy, engagement and creativity [28].

Entrepreneurial success is a complex phenomenon, determined by numerous factors, such as, e.g., socio-cultural and economic factors, but also by education [40]. There are several reasons to promote entrepreneurial education [28]. The need to support early stage entrepreneurs through continuing education and training is seen, e.g., in "that only
$46 \%$ of products introduced to the market are considered successful" [34].

Women entrepreneurs are less likely to have formal education in business and often lack experience in managerial positions compared to male entrepreneurs [41]. The gender-related differences in business performance have recently been studied in Germany. Gottschalk and Niefert [18] analyzed the performance of about 4,700 German startup firms within a maximum period of four years after their foundation, based on data from the KfW/ZEW Start-Up Panel. Performance was operationalized with the indicators of sales, employment growth, and return on sales. Gottschalk and Niefert found that women-owned firms underperform compared to male-owned companies [18]. Differences in founders' human capital explain a considerable part of the 
variance in employment growth and sales, whereas, however, the contribution of the experience variable is greater than that of formal academic training.

To support early stage women entrepreneurs there is a need to increase their performance and growth potential through entrepreneurial education and training. But because little research is available on effective entrepreneurship education and training for women [10], it would be difficult to design suitable learning programs for entrepreneurial development of early stage women entrepreneurs.

The design of effective entrepreneurship education and training for early stage women entrepreneurs, which "....is a complex and multidimensional task" [10], requires a sound theoretical and empirical foundation. The objective of the study is thus to develop theoretically and empirically based entrepreneurship education and training for early stage women entrepreneurs [10].

Because Germany and Ireland are among the innovationdriven European economies with relatively low female TEA rates (Germany: $3.29 \%$ of the female population between 1865 years; Ireland: $5.76 \%$ ) [25], the focus of this study is placed exemplarily on early stage women entrepreneurs in Germany and Ireland. This research should increase our understanding of how to develop evidence and theory based developmental and educational programs for early stage women entrepreneurs.

\section{Literature Review}

The significant growth we have witnessed in entrepreneurship education and training is the result of an economic transformation that is characterized by rapidly changing technology and constantly evolving business models [14]. Demand in the area of entrepreneurship education and training, on the part of both practitioners and academics, is continuing to receive increased attention.

Entrepreneurship education, which can be performed at different levels of the educational system [38], is offered not only at universities, but also within the further and adult education sectors. In the following, entrepreneurship education and training is related to professional development and further education that "... provides tools to... practicing entrepreneurs to launch a new business or to grow an existing business ..." [10]. A general goal of entrepreneurship education and training has been regarded as developing entrepreneurial effectiveness which results in intended outputs.

The pioneering work on modeling entrepreneurship education dates from Alan Gibb's 1986/1987 publication "Education for Enterprise: Training for Small Business Initiation - Some Contrasts." Much research has been devoted to modeling types of education and training programs for entrepreneurs [e.g. 12, 17, 21]. This has been a challenge since the very beginning of this research program and has resulted in problems due to differentiation and disaggregation of concepts and objectives [20-21]. While there is excellent work by scholars in this research field, researchers still lack suitable frameworks to guide their research, practices and policies [27]. As a response to this call, Kyrö contributes in a recent study with a conceptual approach to entrepreneurship education by building a bridge between the conceptual discussion of educational science and entrepreneurship [27]: Kyrö places the center of learning processes in Entrepreneurship Education and Training on action-orientation, autonomy and the interplay between risk and responsibility.

To promote early stage women's entrepreneurship education and training, research should aim at developing high quality programs that contribute to positive outcomes. For education in entrepreneurship or enterprising behavior, the OECD states: "Although the importance of education for entrepreneurship, or enterprising behaviour, has been widely acknowledged, this has not necessarily been reflected in the systematic application or evaluation of education for entrepreneurship programmes [38]."

One of the studies in which a systematic evaluation was made was conducted by [16]. They showed that an intervention based on action regulation theory affects the success of firms in Uganda by modifying entrepreneurs' actions. Action principles are the central didactic component of this entrepreneurship program, which was targeted at both female and male entrepreneurs. Another theory-based entrepreneurship training and randomized field intervention study was done on Achievement Motivation Training. This training has the objective to increase the achievement motivation [32] of entrepreneurs in India. Evaluation found positive effects on Indian entrepreneurs' achievement motivation. Of the Entrepreneurship Education and Training Programs that have been developed and scientifically validated, so-called Empretec Entrepreneurship Training is the one that "set the tone for much of the entrepreneurship development that has taken place over the last forty years" [44]. Empretec methodology was developed [19] on the basis of studies of personal entrepreneurial competencies (PECs). However, for the Empretec program, which has so far been implemented in 29 developing countries, including six of the least-developed countries, only a limited number of impact assessments have been made. Evaluation studies most often use a 'before-and-after' approach, where PECs identified from interviews of subjects, chiefly males, are compared to PECs measured several months after the workshop [30]. We could find only one evaluation study based on an experimental design using two comparison groups [19]. Moreover, the study was criticized for using a context that is less relevant for other countries [19].

Furthermore, the presented studies do not indicate any indepth analysis of the gender category. Despite the increasing worldwide importance of entrepreneurship education and training for women, there is "remarkably little empirical or academic research that pertains to effective entrepreneurship education and training for women" $[10,42]$.

Not only is it important to systematically evaluate entrepreneurship programs, but also to design entrepreneurship education and training in an empirical and 
theoretical way in order to ensure entrepreneurship education and training effectiveness.

[10] developed a framework comprising the core factors that contribute to effective entrepreneurship and education and training. The Entrepreneurship Education and Training Effectiveness Framework consists of the core components [10] of goals and programmatic elements: Goals are understood as independent variables that steer the choice and design of the program elements. Program elements, such as for example trainers, curriculum, and wrap-around services, are to be determined before the background of the program goals, as program elements influence a program's effectiveness [10]. Serving as moderators within this framework are three further components: (1) individual characteristics of program participants (human factors, such as intentions and goals, entrepreneurial capabilities, cognition and personality), (2) contextual characteristics of the environment in which the program is implemented (culture, economic development and organizational quality), and (3) funding (from donors, grants, or tuition). These three components influence a program's effectiveness in achieving its goals. The goals should be defined at the beginning of program development [10]. Before starting to select and implement program elements, it is necessary to account for the characteristics of participants (human factors), the program's contextual environment, and the availability of funding for operations [10]. "When the program design phase has been executed effectively - goals x moderators (human factors, contextual environment, funding) $\mathrm{x}$ elements of the program - the elements of the program should result in successful achievement of the program's goals. In other words, in a circular fashion, start with the goals in design, consider the moderators, and end with the goals in achievement." [10]

These components, program goals, program elements, as well as the participants' characteristics (human factors), the program's contextual environment, and the availability of funding for operations provide a framework for designing a theoretically and empirically based program to help early stage women entrepreneurs increase their entrepreneurial success.

\section{Program Design}

\subsection{Component: Goals}

The entrepreneurship education and training program is designed to enhance the capacities of early stage women entrepreneurs of micro- and small enterprises from the service sector in Germany and Ireland and increase their overall entrepreneurial success.

The design of the entrepreneurship education and training program is embedded in an empirical study which identified competencies that affect the entrepreneurial success of women entrepreneurs. This study aims at supporting the acceptance of such program within early stage women entrepreneurs [43]. Based on this study of 306 women entrepreneurs (200 women entrepreneurs from Germany and 106 women entrepreneurs from Ireland), a structural equation model was developed. The results of this study reveal that, as a higher order latent construct, entrepreneurial competencies have a major impact on entrepreneurial success (.559; $\mathrm{p} \leq .001)$ [43]. Entrepreneurial competencies of women entrepreneurs in Germany and Ireland can be operationalized by a set of six first-order factors, including functional taskrelated managerial skills, entrepreneurial characteristic adaptations of personal efficacy and orientations of competition, risk-taking and innovation, and a founder and innovator identity. The theoretical construct of entrepreneurial performance, which consists of the dimensions of economic, individual and societal performance, was expanded and enhanced with the dimensions of performance quality, customer satisfaction and productivity.

This study informs the program design about which competencies should be furthered to enhance entrepreneurial success. To define program goals we integrate empirical with theoretical perspectives: The empirical perspective focuses on personality-related factors of our study which predict entrepreneurial success. The theoretical perspective is related to economic and other social and educational science theories that can be drawn on to enhance personality-related factors of success. Moreover, from our study we not only derive competencies to be furthered, but also define basic skills that we consider essential.

The program goals related to basic skills are:

- Participants will learn to analyze how a company creates, develops and delivers a service to generate the resources in order to make the company sustainable.

- Participants will learn to analyze the environmental changes that affect the entrepreneurial success of a company and will analyze how the organization is prepared to respond to these changes.

Program goals derived from the findings of our study are:

(a) Enhancing task-related skills loading on the factor of managerial skills.

The best predictor of entrepreneurial competencies is the factor of task-related managerial skills with a strong impact (.703). The following task-related skills load on the first order factor of functional skills: knowing and managing technological changes $(=.681 ; \mathrm{p} \leq .001)$, managing changes in production or market needs $(=.448 ; \mathrm{p} \leq .001)$, increasing requests for services $(=.647 ; \mathrm{p} \leq .001)$, managing general marketing strategies $(=.596 ; \mathrm{p} \leq .001)$, improving quality $(=.584 ; \mathrm{p} \leq .001)$, managing an increase in customer/consumer complaints $(=.569 ; \mathrm{p} \leq .001)$, and dealing with increased competition (=.689; $\mathrm{p} \leq .001)$. [43] Because of the short program duration, we focus on four skills as described in the following.

Increasing requests for services.

Participants in the program will increase service request through product and market development. 
Knowing and managing technological changes.

Participants will manage technological changes through process and product innovation.

Managing an increase in customer/consumer complaints.

Participants will reduce complaints through complaint analysis and improving customer satisfaction.

Dealing with increased competition.

Participants will deal with increased competition by improving customer relations and developing fidelization strategies consistent with their business model.

(b) Enhancing belief in entrepreneurial self-efficacy.

Belief in entrepreneurial self-efficacy was the second strongest predictor of entrepreneurial competencies (.667) [43].

The first order factor of personal entrepreneurial selfefficacy is predicted by the indicators of self-efficacy in recognizing business opportunities $(=.729 ; \mathrm{p} \leq .001)$, creating and developing new products and services $(=.728 ; \mathrm{p} \leq .001)$ and thinking in creative ways to solve problems $(=.680$; $\mathrm{p} \leq$.001) [43]. Participants will strengthen their entrepreneurial self-efficacy by recognizing business opportunities and creating and developing new products and services.

(c) Enhancing competition, innovation and risk-taking orientation.

In the model, three first-order factors, orientation of competition, orientation of risk-taking, and orientation of innovation, exert direct influence on entrepreneurial competencies.

For each of three entrepreneurial orientation factors, competition, innovation and risk taking, the impact is strong ranging from $=.505(\mathrm{p} \leq .001)$ to $=.510(\mathrm{p} \leq .001)[43]$.

Enhancing competition orientation.

Women entrepreneurs will direct company strategy towards competition by improving customer relations and developing fidelization strategies consistent with their business model.

Enhancing innovation orientation.

Women entrepreneurs will direct company strategy towards innovation through process and product innovation.

Enhance risk orientation.

Women entrepreneurs will direct their company strategy towards risk orientation through enhanced entrepreneurial self-efficacy. Krueger and Dickson found that subjects who believe they are competent in a specific task see more opportunities in risky choices [26].

(d) Enhancing a sense of entrepreneurial identity.

Women entrepreneurs will strengthen their sense of founder and innovator identity with a narration of founding and innovating in their business.

The performance outcome of the program refers to the measured construct of entrepreneurial success. According to the measurement model, economic performance will be measured by sales, market share, and offered products and services. The dimension of individual performance consists in an assessment of enhancing family relationships, enhancing emotional-affective relationships and reconciling professional and personal life. Social performance will be measured by assessing public visibility and contributions to society. The construct of entrepreneurial success is expanded with the dimensions of performance quality, customer satisfaction and productivity, which will also be measured for outcome. (for the constructs, see [43])

Program goals refer to entrepreneurial capabilities, characteristic adaptations of personal entrepreneurial self-efficacy, innovation, risk and competition orientation, entrepreneurial identity and the outcome of entrepreneurial success.

\subsection{Component: Moderators}

According to [10], individual characteristics of program participants (human factors), contextual characteristics of the environment where the program is held and funding (from donors, grants, or tuition) moderate the effectiveness of programs in achieving their goals. In the following, moderators in the program design will be considered.

Individual Characteristics

There are individual characteristics of entrepreneurs which affect the success of entrepreneurship education and training programs. The program target group is early stage women entrepreneurs of micro- and small enterprises from the innovation-driven economies of Germany and Ireland. Early stage women entrepreneurs will be recruited from the service sector. The early-stage Total Entrepreneurial Activity Rate (TEA), a key measure of the global report on assessing entrepreneurship [3], includes persons in the process of starting a business (nascent entrepreneurs) as well as persons running a new business beyond the nascent stage (three months), but before the established business phase (threeand-a-half years). Early stage women entrepreneurs are operationalized as enterprise owners with at least one employee but still in the early stage phase.

Different capabilities and motivations of learners result in different learning performance, and education and training outcomes, regardless of the program's methods and practices [10]. Based on the characteristics of our sample, we assume that most participants have secondary school and Bachelor degrees [43].

A rigorous selection process can guide recruitment of participants according to prerequisites critical for reaching desired learning results and performance outcomes. In order to help identify women entrepreneurs with the right abilities, needs, interests, intentions and level of commitment to the program and its outcomes, and to be able to precisely identify target participants of the implemented program, we include a questionnaire in the program evaluation. The analysis has the function to reveal prerequisites which predict outcomes, but will not be promoted by the program in order to design and implement a selection process for participants.

In addition to this selection preparation process, we implement an in-depth assessment of matches between learning and program objectives, in order to individualize the learning process. The Entrepreneurship Education and Training Program is based on a thorough analysis of participants' training needs. Beginning with an initial 
common learning unit for all participants, the learner chooses individual learning objectives from empirical-based program objectives that are critical to entrepreneurial success. This selection results from a process of integrating individual and organizational perspectives:

- reflecting on and assessing individual entrepreneurial competencies via a competence matrix, and

- reflecting on the assessment of the business model and business performance via analysis.

Contextual characteristics of the environment

Economic, political, and social factors, such as, for example, culture and economic development, can facilitate or impede learning results or performance outcomes [10].

Entrepreneurship education and training programs for women entrepreneurs will be more effective in cultures characterized by planning and forecasting, which reflects greater future orientation, rewarding innovation and excellence, which characterizes higher performance orientation, encouraging upward communication and mobility, which is typical of lower power distance, promoting gender-egalitarianism, and minimizing uncertainty avoidance [10].

Both Germany and Ireland are innovation driven countries. To identify the above mentioned cultural dimensions, I refer to the GLOBE Study of 62 Societies, based on results from about 17,300 middle managers of 951 organizations in the food processing, financial services, and telecommunication service industries [22].

The scores in Ireland and Germany on the Future Orientation Societal Practices Scales are, with 3.98 (Ireland) and 3.95 (Germany), similar with a midpoint of 4.0 on the scale of 1 to 7 (Range: 2.88 to 5.07; standard deviation: 0.46) [22]. Higher scores indicate greater future orientation. Regarding the cultural dimension of Performance Orientation Societal Practices, Ireland has with 4.36 a higher practice score compared to Germany with 4.25 (mid-level average rating of 4.10 with a range of 3.20 to 4.94) [22]. Higher scores indicate greater performance orientation. Germany with 5.25 has slightly higher Power Distance Societal Practices scores than Ireland with 5.15 (Mean: 5.17). Higher scores indicate greater power distance. In terms of the cultural dimension of Gender Egalitarianism Societal Practices, Ireland with 3.21 has a higher practices score than Germany with 3.06 (Mean: 3.37; standard deviation: 0.37) [22]. Lower scores indicate greater male domination. The score for Society Uncertainty Avoidance Practices is 5.22 for Germany and 4.30 for Ireland. (Mean: 4.16; standard deviation: 0.60) [22]. Higher scores indicate greater uncertainty avoidance practices. For this score the difference between Ireland and Germany is the greatest.

The Ease of Doing Business Index [45] is an index created by the World Bank Group. Economies are ranked on their ease of doing business, from 1 to 190. A high position means that the environment is favorable to starting and operating a company. In the Ease of Doing Business Rank Index Ireland ranks 17 th compared to Germany, which is ranked 18th.
The Global Entrepreneurship Index (GEI) [13] is an annual index that measures Entrepreneurial Performance in 137 countries around the world and provides a detailed look at nations' entrepreneurial ecosystems and their strengths and weaknesses [1]. In 2017, Ireland ranked $9^{\text {th }}$ in the GEI-Rank with a score of 71 and Germany lagged a little behind in $12^{\text {th }}$ place with 64.9.

Although the scores for culture and economic development are comparable between these two countries, the environmental context in Ireland is slightly more conducive to effective entrepreneurial education for women entrepreneurs than that in Germany.

Funding

The funding of entrepreneurship education and training programs is another important moderator within the Program Effectiveness Framework [10]. This factor moderates training effectiveness. The implementation of the pilot program will be funded by a grant. For the period after the funding period, participating women entrepreneurs will be asked to pay program tuition, insofar as they can afford this.

\subsection{Component: Program Elements}

The entrepreneurship education and training course, which has been designed with a blended learning model, consists of four modules, one face-to-face opening session and three online modules delivered via a digital platform. The duration of the program is four months. The estimated work-load is five to eight hours per week, with a maximum of 128 hours. The proposed number of participants is at least 25 women entrepreneurs from each country. Figure 1 shows the structure of the blended-learning model, which consists of one off-line module and three online modules.

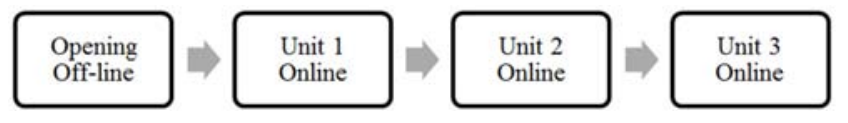

Figure 1. Structure of the blended learning design.

Because the course is targeted at women entrepreneurs in two countries, the program is divided into a short off-line unit (Opening Session) with an approximate duration of three hours and a long online-segment consisting of three units lasting a total of four months. The Opening Session is intended to introduce participants to the program, trigger interest with a keynote speech on women entrepreneurship, and initiate networking. The online program consists of two consecutive units (Unit 1 and Unit 2) and one transversal unit (Unit 3).

Unit 1: The Essence of Entrepreneurship.

Unit 2: The Challenges for Business Performance.

Unit 3: Networking.

Unit 1 lays the foundation for the individual learning process by gaining understanding and acting on one's own business model and by giving meaning to one's own entrepreneurial story. Based on the assessment of their own business and on the assessment of their entrepreneurial competencies, women participants will be able to define their 
learning objectives within the program objective framework, allowing them to select for Unit 2 a maximum of two entrepreneurial problems from four problem areas, the socalled tracks. Parallel to these two units there will be a networking unit (Unit 3). Throughout the learning program, women entrepreneurs will receive tools and support to further autonomous and action-oriented entrepreneurial learning [27].

\section{Learning facilitators}

The facilitators form a team consisting of faculty, experienced practicing entrepreneurs, peer-groups of women entrepreneurs, and business students. Because the entrepreneurship education and training program is based on problem and action orientation [27], learners will collaborate in teams. Each team will consist of about four persons. Business students from relevant disciplines, participants of the program, and senior experienced entrepreneurs will be learning facilitators. Faculty will serve as keynote speakers during the opening session.

Curriculum

The program is organized in three units, eight tracks and seventeen modules (see Table 1).

Table 1. Curriculum of the entrepreneurship education and training program.

\begin{tabular}{|c|c|c|}
\hline Unit & Track & Modules \\
\hline \multirow{5}{*}{1 The Essence of Entrepreneurship } & \multirow{2}{*}{ Reflecting on Yourself as an Entrepreneur. } & Your Founding and Innovating Story \\
\hline & & Your Life Story as an Entrepreneur \\
\hline & \multirow{2}{*}{ Understanding your Company. } & Business Model \\
\hline & & Business Opportunity \\
\hline & Assessing your Entrepreneurial Competencies. & $\begin{array}{l}\text { Self-assessment of your Entrepreneurial Competencies } \\
\text { Your Learning Goals }\end{array}$ \\
\hline \multirow{4}{*}{$\begin{array}{l}2 \text { The Challenges for Business } \\
\text { Performance }\end{array}$} & Increasing Requests for Services. & $\begin{array}{l}\text { Product Development } \\
\text { Market Development }\end{array}$ \\
\hline & Knowing and Managing the Technological changes. & $\begin{array}{l}\text { Process Innovation } \\
\text { Product Innovation }\end{array}$ \\
\hline & Managing an Increase in Customer Complaints. & $\begin{array}{l}\text { Complaint Analysis } \\
\text { Customer Satisfaction }\end{array}$ \\
\hline & Dealing with the Increased Competition. & $\begin{array}{l}\text { Customer Relationship } \\
\text { Strategic Planning } \\
\text { Interacting in a Solution-Focused Way }\end{array}$ \\
\hline 3 Networking & Networking & $\begin{array}{l}\text { Examining Goal-Preventing Assumptions } \\
\text { Inspire Young Women to Become Entrepreneurs }\end{array}$ \\
\hline
\end{tabular}

Delivery format

The entrepreneurship education and training program is based on problem and action orientation, combined with elements of reflective, narrative and collaborative learning. By selecting this didactic strategy, the focus is put on the learner and the individual entrepreneurial problems to be solved through collaborative learning and individual reflection and narration processes.

(a) To enhance task-related managerial skills

A standardized learning process is designed to enhance task-related managerial skills. The process entails the following steps:

Define learning objectives based on self-assessment of competencies and assessment of one's own business model and become aware of the relevant skill related knowledge.

Read texts, use supplemental resources and watch video clips.

Answer questions for understanding, applying, analyzing, evaluating and creating skill-related learning results/products/entrepreneurial problem solutions with the support of the learning team and by means of learning activities.

Present developed problem solutions to a learning team to receive feedback and reflect the learning process.

(b) To enhance self-belief in one's entrepreneurial selfefficacy

According to Bandura [5], there are two effective sources for developing self-efficacy: mastery experiences and second- hand experiences. Ways to enable participants to acquire mastery and second-hand experiences are the following:

Strengthening belief in self-efficacy through mastery experiences will be realized in this program through individual competence-based learning paths customized to the competencies of learners and a learning unit based on constructivist didactic principles [24].

Individualization of learning objectives will enable learners to successfully complete exercises with increasing levels of difficulty. Within each set of exercises, continuous effort is necessary to overcome obstacles. Feedback is structured in such a way that attribution processes contribute to strengthening belief in self-efficacy.

The networking activity "Interact in a Solution- Focused Way" allows the participants to receive direct feedback to problems and to give feedback to problems of peers. This activity started with a presentation of experienced success by all participants to enhance the entrepreneurial self-efficacy.

Program participants will learn to overcome barriers that interfere with defined entrepreneurial goals. Through reflecting on relevant entrepreneurial goals, goalachievement blocking behavior, motives of behavior and major assumptions, participants will be enabled to effectively approach defined goals and enrich their cognitive perspectives.

The other effective way to strengthen belief in one's selfefficacy is through second-hand experiences provided by social models. Seeing other women entrepreneurs like 
oneself succeed through effort strengthens the conviction of participant observers that they too will be able to master comparable challenges that must be met on the path to entrepreneurial success.

To obtain second-hand experiences in the program biographical videos of successful women entrepreneurs, and written narrations of founding stories will be presented by each participant. [The second option will be realized only if participants give written consent for their stories to be publicly presented].

Modeling provides a social standard against which women can judge their own capabilities and makes it possible to acquire better means to increase beliefs of self-efficacy by observation.

(c) To enhance Orientations to Competition, Innovation and Risk-taking

Orientations of competition, innovation and risk-taking will be regarded as characteristic adaptations [31]. They are oriented towards a firm's level of entrepreneurship. Changing characteristic adaptations as "culturally conditioned phenomena" [33] is about changing habits, goals and attitudes. "... sustained change of characteristic adaptions would require people to adopt new cognitive perspectives and goals ..." [33]

To enhance characteristic orientations, the already mentioned method of reflecting on goal blocking behavior will be used to modify major assumptions and to adopt new cognitive perspectives and goals. Modules related to competition and innovation will be offered. Interacting with beliefs of personal competence and organizational performance involves risk-taking. By enhancing task-related belief in self-efficacy, we expect that the orientation to finding more opportunities in risky choices will also be furthered. For this reason, this objective will not be addressed by a specific learning and development method.

(d) To enhance the sense of identity

For enhancing the sense of identity, activities, social interactions and meaning and significance building processes are critical methods [23]. A person can gain knowledge of herself if she has an opportunity to observe herself in action [23]. "The mechanisms underlying the role of social interaction ... are information and support, identification and social validation and comparison" [23]. Life events play a critical role for identity transition. "What turns any event into a trigger is the meaning a person derives from it" [23]. As a consequence of these mechanisms and factors that explain the sense of identity, the didactic framework to enhance the innovator and founder identity can be described as follows:

Through activities of innovating processes and services in her own company, the participant will have the opportunity to observe herself and to gain knowledge about herself as an innovator.

The innovating activities are regarded as events from which participants can derive meaning. This meaning will be reflected in the exercise to narrate a written story of an innovating activity. Experiences have little value if they are not connected to or fused with stories [46]. Unity that triggers the sense of significance is found in a story that is not already present in the action [46]. Because early stage entrepreneurs have already founded their companies, the goal of enhancing founder identity will be addressed by elaborating meaning and significance making processes. The exercise intended to enhance founder identity will be to narrate a written story of becoming a founder.

In terms of social interactions, the program offers three ways in which the sense of identity will be strengthened:

The blended learning setting is a social learning environment which will provide opportunities for participants to engage actively with content related to enhancing entrepreneurial success. Through social interactions, the learner will receive information and support. The program gives learners an opportunity for social validation and comparison by receiving and offering feedback on the results of learning and by learning about social norms against which women can judge their own capabilities.

Videos of successful female entrepreneurs show potential models. Modeling is an effective way to trigger identification processes. Identifying with other entrepreneurs motivates women entrepreneurs to assimilate the requirements of a founder or innovator role [23].

The networking activity "Inspiring Young Women to Become Entrepreneur" aims at designing and implementing news ways for motivating young women for entrepreneurship. The activity consists of inviting a young woman to spend a day with her to inspire the young woman in a creative way to become entrepreneur. By inspiring young women entrepreneurial meaning needs to be derived from being an entrepreneur and communicated.

Because identity transition can be understood as a developmental process, we assume that in this program, with its duration of only four months, the degree of identity strengthening may be limited.

Media

Media provided in the program include readings, videos and supplemental resources. Content will be offered on the learning platform in German and English.

The readings present powerful managerial methods. They are written at appropriate readability levels and structured in a clear way: Introduction, Presentation of Methods and Summary. The narrative and personal style of the texts, which are enriched by examples and questions, will facilitate the process of reading and understanding.

The development of the videos is embedded in an 'edutainment' approach in order to facilitate the learning process for early stage women entrepreneurs. A web based series with biographies of successful women entrepreneurs has been designed to trigger their personal entrepreneurial identification as innovators and founders and strengthen their belief in their own entrepreneurial efficacy. The videos will emphasize social modeling within the context of entertainment featuring main characters that are successful female entrepreneurs, and will be embedded in a post-discussion session. To produce these edutainment videos, a validation process was implemented for the messages, formats and characters. Further video clips were 
designed to visualize content. Supplemental resources such as links and literature are included.

\section{Discussion}

By designing this theory and empirical-based entrepreneurship education and training program for early stage women entrepreneurs in Germany and Ireland, the bridge between the conceptual discussion of educational science and entrepreneurship should be strengthened [27]. This Entrepreneurship Education and Training is built on the core dimensions of entrepreneurship education [27], action-orientation, autonomy and the interplay between risk and responsibility. Action-orientation is reflected in acting in learning to solve business problems in one's own company. Autonomy is manifested by selecting individual learning objectives. Interplay between risk and responsibility is shown through taking responsibility for individual and organizational development, which participants will learn is in part a risk-taking process. Because we expand on these core dimensions, entrepreneurial learning can be understood as learning through entrepreneurial action, reflection, and narration.

We will evaluate the program using a pre-test-post-test control group design with a program and control group. The programs will be evaluated in each country.

As the entrepreneurial success is determined by numerous factors, such as, e.g., socio-cultural, and economic factors, but also by education, there is limited influence of learning on entrepreneurial success. Entrepreneurial training and education programs therefore need to be embedded in environmental and cultural interventions and changes, such as, promoting gender-egalitarianism.

\section{Conclusion}

The design of the program targeted at early stage women entrepreneurs not only shows how the core components of an entrepreneurial education and training program can be designed for the specific target group of early stage women entrepreneurs in Germany and Ireland, but also how the Entrepreneurship Education and Training Effectiveness Framework can be enriched. We include the process of deriving program and learner goals as a critical starting point for designing programs affecting both learning performance and outcome.

Finally, the program must also be considered in light of its limitations. Given the sample used in the empirical study, it was not possible to control for business sectors and regional areas in the explanation of hypothetical relations. Future research should, for example, include a sample focused only on the service sector. Besides the program goal results from the validated instruments used in the study, it should be tested which further predictors should be addressed by the Entrepreneurship Education and Training Program. The empirical study was conducted using self-assessment. These data should be complemented by objective data in order to enhance the validity of program goals.

The environmental analysis shows, that the scores for culture and economic development are slightly more conducive to effective entrepreneurial education for women entrepreneurs in Ireland than in Germany. Hence, we can assume that there is a higher probability in Ireland than in Germany that program goals happen. Because of the environmental context in Germany the program needs to be accompanied by events and activities to show the moderating impact of culture and economy on the learning process to become a successful entrepreneur.

\section{Acknowledgements}

This project has received funding from the European Union's Horizon 2020 research and innovation programme under grant agreement No 645441. The author would like to thank the European Commission for funding this research and innovation project.

\section{References}

[1] Acs, Z, Szerb, L. \& Autio, E. (2015). The Global Entrepreneurship Index 2016. Washington, D.C.: The Global Entrepreneurship and Development Institute.

[2] Ahl, H. (2006). Why Research on Women Entrepreneurs Needs New Directions. Entrepreneurship Theory and Practice, 5(30), 595-621.

[3] Amorós, J. E., Bosma, N. \& Global Entrepreneurship Research Association (GERA). (2014). Global Entrepreneurship Monitor. 2013. Global Report. Babson College; Universidad del Desarrollo; Universiti Tun Abdul Razak; London Business School.

[4] Azim, M. T. \& Al-Kahtani, A. H. (2015). Designing entrepreneurship education and training program: In search of a model. Journal of Economics and Sustainable Development, $6(22), 112-127$.

[5] Bandura, A. (1969). Social-learning theory of identificatory processes. In: Goslin, D. A. (Ed.) Handbook of Socialization Theory and Research, pp. 213-262. Chicago, IL: Rand McNally \& Company.

[6] Brush, C. G. (1992). Research on women business owners: Past trends, a new perspective and future directions. Entrepreneurship Theory and Practice, 16(4), 5-30.

[7] Brush, C. G. (1997). Women-owned businesses: Obstacles and opportunities. Journal of Developmental Entrepreneurship, 2(1), 1-24.

[8] Brush, C. G., de Bruin, A. \& Welter, F. (2009). A genderaware framework for women's entrepreneurship. International Journal of Gender and Entrepreneurship, 1(1), 8-24.

[9] Bryant, P. (2006). Improving Entrepreneurial Education through Self-Regulatory Skills. The NCIIA, 279-289. Available at: http://citeseerx.ist.psu.edu/viewdoc/download?doi=10.1.1.319 $.1621 \&$ rep=rep1\&type=pdf Accessed 14 February 2017. 
[10] Bullough, A, de Luque, M. S., Abdelzaher, D. \& Heim, W. (2015). Developing Women Leaders Through Entrepreneurship Education and Training. Academy of Management Perspectives, 29(2), 250-270.

[11] European Commission (2010). Mitteilung der Kommission: Europa 2020. Eine Strategie für intelligentes, nachhaltiges und integratives Wachstum. Available at: http://eur-lex.europa.eu/ Accessed 10 February 2017.

[12] Garavan, T. N. \& O'Cinneide, B. (1994). Entrepreneurship Education and Training Programmes: A Review and Evaluation Part 1. Journal of European Industrial Training, 18(8), 3-12.

[13] GEDI (2017). Global Entrepreneurship Index. Available at: https://thegedi.org/global-entrepreneurship-and-developmentindex/ Accessed 08 February 2016.

[14] Gibb, A. A. (2002). In pursuit of a new enterprise and entrepreneurship paradigm for Learning: creative destruction, new value, new ways of doing things and new combination for knowledge. International Journal of Management Review, 4(3), 233-269.

[15] Gibb, A. A. (1986/87). Education for Enterprise: Training for Small Business Initiation - Some Contrasts. Journal of Small Business and Entrepreneurship 4(3). Winter 1986/87.

[16] Glaub, M. E., Frese, M., Fischer, S. \& Hoppe, M. (2014). Increasing Personal Initiative in Small Business Managers or Owners Leads to Entrepreneurial Success: A Theory-Based Controlled Randomized Field Intervention for EvidenceBased Management. Academy of Management Learning \& Education, 13(3), pp. 354-379. Available at: http://dx.doi.org/10.5465/amle.2013.0234

[17] Gorman, G., Hanlon, D. \& King, W. (1997). Some research perspectives on entrepreneurship education, enterprise education and education for small business management: a ten year literature review. International Small Business Journal, 15(3), 56-78.

[18] Gottschalk, S. \& Niefert, M. (2011). Gender Differences in Business Success of German Start-Up Firms. ZEW - Centre for European Economic Research Discussion Paper No. 11019. Available at ftp://ftp.zew.de/pub/zewdocs/dp/dp11019.pdf Accessed 14 February 2017.

[19] Grossmann, M. (2005). The Impact Challenge: Conducting Impact Assessments for the EMPRETEC Programme A Background Note. University of Oxford. Available at: http://www.empretec-

assessment.org/documents/Documents/English/Background/B ackground.pdf Accessed 10 February 2017.

[20] Henry, C., Hill, F. \& Leitch, C. (2005a). Entrepreneurship education and training: can entrepreneurship be taught? Part II. Education + Training, 47(3), 158-169.

[21] Henry, C., Hill, F. \& Leitch, C. (2005b). Entrepreneurship education and training: can entrepreneurship be taught? Part I. Education + Training, 47(2), 98-111.

[22] House, R. J., Hanges, P. J., Javidan, M., Dorfman, P. W. \& Gupta, V. (2004). Culture, Leadership, and Organizations: The Globe Study of 62 Societies. Thousands Oaks, CA.

[23] Ibarra, H. (2005). Identity Transitions. Possible Selves, Liminality and the Dynamics of Career Change. 2005/51OB. Revised version of $2005 / 24 /$ OB. Working Paper Series. Fontainebleau: INSEAD.
[24] Kegan, R. (2014). Wie wir unserem Selbst im Weg stehen. Harvard-Professor Robert Kegan im Gespräch. OrganisationsEntwicklung 1, 49-55.

[25] Kelley, D., Singer, S. \& Herrington, M. (2016). Global Entrepreneurship Monitor: Global Report 2015. www.gemconsortium.org. Accessed 25 November 2016.

[26] Krueger, N. \& Dickson, P. R. (1994). How Believing in Ourselves Increases Risk-Taking: Perceived Self-efficacy and Opportunity Recognition. In: Decision Sciences, 25(3), 385400.

[27] Kyrö, P. (2015). The conceptual contribution of education to research on entrepreneurship education, Entrepreneurship \& Regional Development, 27(9-10), 599-618, doi: $10.1080 / 08985626.2015 .1085726$

[28] Lackéus, M. (2015). Entrepreneurship in Education. What, Why, When, How. Entrepreneurship 360. Background Paper. EC, LEED, OECD.

[29] Lerner, M. \& Almor, T. (2002). Relationships among strategic capabilities and the performance of women-owned small ventures. Journal of Small Business Management, 40(2), 109125 .

[30] Lopes, R. M. A. (n. y.). Evaluation and Impact of Empretec - a Competency-Based Training for Entrepreneurs in Brazil: A Comparison between two Studies. Available at: http://www.anpad.org.br/diversos/trabalhos/EnANPAD/enanpad _2004/ECE/2004_ECE2326.pdf Accessed 14 February 2017.

[31] McAdams, D. P. \& Pals, J. L. (2006). A new big five. Fundamental principles for an integrative science of personality. American Psychologist, 61, 204-217.

[32] McClelland, D. C., \& Winter, D. G. (1971). Motivating economic achievement. New York: Free Press.

[33] McCrae, R. (2011) Personality Traits and the Potential of Positive Psychology. In: Sheldon, K. M., Kashdan, T. B, \& Steger, M. F. (Eds.). Designing Positive Psychology: Taking Stock and Moving Forward, pp. 193-206. New York NY: Oxford University Press.

[34] Meffert, H., Burmann, C. \& Kirchgeorg, M. (2012). Marketing. Grundlagen marktorientierter Unternehmensführung; Konzepte - Instrumente Praxisbeispiele (11. überarb. und erw. Aufl.). Wiesbaden: Gabler.

[35] Miller, D. (1983). The correlates of entrepreneurship in three types of firms. Management Science, 29, 770-791.

[36] Mitchelmore, S. \& Rowley, J. (2013). Entrepreneurial competencies of women entrepreneurs pursuing business growth. Journal of Small Business and Enterprise Development, 20(1), 125-142.

[37] Mitchelmore, S. \& Rowley, J. (2010). Entrepreneurial competencies: a literature review and development agenda. International Journal of Entrepreneurial Behavior \& Research, 16(2), 92-111. doi: 10.1108/13552551011026995.

[38] OECD (2009). Evaluation of Programmes Concerning Education for Entrepreneurship. Report by the OECD Working Party on SMEs and Entrepreneurship, OECD.

[39] Osterwalder, A., \& Pigneur, Y. (2010). Business Model Generation. Hoboken, New Jersey: John Wiley \& Sons, Inc. 
[40] Piacentini, M. (2013). Women Entrepreneurs in the OECD: Key Evidence and Policy Challenges. OECD Social, Employment and Migration Working Papers, No. 147, OECD Publishing. doi: 10.1787/5k43bvtkmb8v-en.

[41] Poggesi, S., Mari, M. \& de Vita, L. (2015). What's new in female entrepreneurship Research? Answers from the Literature. International Entrepreneurship and Management Journal. doi: 10.1007/s11365-015-0364-5.

[42] Reay, T., Berta, W., \& Kohn, M. K. (2009). What's the evidence on evidence-based management? Academy of Management Perspectives, 23, 5-18.

[43] Schneider, K. (submitted 2017). Entrepreneurial competencies of women entrepreneurs. Journal of Global Entrepreneurship Research.
[44] Tomecko, J. W. (1996). Training for Success: The Situation and The Challenge. Available at: http://cefe.gtz.de/products/papers/214311.html Accessed 14 February 2017.

[45] The World Bank. (2016). Doing Business. Economy Rankings. Available at: http://www.doingbusiness.org/rankings Accessed 14 February 2017.

[46] Widdershoven, G. A. M. (1993). The Story of Life: Hermeneutic Perspectives on the Relationship Between Narrative and Life History. In: Josselson, R. \& Lieblich, A. (Ed.): The Narrative Study of Lives. Vol. 1, pp. 1-20. Newburg Park: Sage Publications. 